\title{
HUMANITARIAN INTERVENTION IN AFRICA: TOWARDS A NEW POSTURE
}

\author{
Lt Richard Gueli* \\ Faculty of Military Science, Stellenbosch University
}

\begin{abstract}
'Throughout history it has been the inaction of those who could have acted, the indifference of those who should have known better, the silence of the voice of justice, that has made it possible for evil to triumph.' - Emperor Haile Selassie of Ethiopia.
\end{abstract}

\section{Introduction}

Article 2 of the Charter of the United Nations (UN) implicitly recognises the validity of the concept of non-intervention, when it articulates 'nothing contained in the present Charter shall authorise the $[\mathrm{UN}]$ to intervene in matters which are essentially within the domestic jurisdiction of any state'. This principle has been designed to reassure member states of the UN that their sovereign rights are respected, and that they should never become targets of intervention. ${ }^{2}$ If this is indeed the case, why then bother with the notion of intervention?

Considering the anticipation of an era characterised by international peace, security, and co-operation at the end of the Cold War, high expectations appear to have instead given way to disorder and disillusionment as a result of the intensifying conflicts that have arisen from human catastrophes in economically and politically disadvantaged countries in many parts of the world. In Africa's case, it appears that the more intense and destructive the conflict, as in the case of Burundi, Liberia,

This article was initially handed in as a graduate research paper in the School for Security and Africa Studies. The author would like to thank the following scholars for helpful comments on earlier drafts of this article: Prof Theo. Neethling, Lt Col Abel Esterhuyse, Lt Col Francois Vreÿ from the Faculty of Military Science, Stellenbosch University, and Lt Col Inus du Plessis from the Centre for Military Studies, Stellenbosch University.

1 UN, The Charter of the United Nations, Article 2. The Charter of the United Nations may be found in the United Nation official website at http://www.un.org/aboutun/charter/index.html.

R. Falk, 'The new interventionism and the Third World', Current History, 98/631 (November 1999), p 370. 
Rwanda, Somalia and the Democratic Republic of Congo (DRC) exemplify, the greater is the paralysis of the international community in acting decisively to bring an end to the violence.

Moreover, the role of the classical peacekeeper - to monitor the implementation of an agreement between two or more parties to a conflict, and to do so usually unarmed - often seems to be 'the exception rather than the rule'. In reality, conflicts in Africa (and other parts of the world), often fuelled by deeprooted hatred and involving countless armed factions, as well as the abundance and availability of weapons and ammunition, confront peace forces with a highly constrained and unsafe operational environment. Beyond this, the role of the UN in this 'new world disorder' has been unclear, particularly in its responsibility to mobilise the political will or the capabilities to address internal problems in socalled weak states.

Against this backdrop, humanitarian intervention may emerge as one amongst other fundamental issues that, if conducted in a legitimate or, at least coherent way, could positively contribute to the management and perhaps the resolution of violence on the African continent.

The central argument of this paper attempts to demonstrate that, should any government be guilty of the most heinous crimes recognised under international law (genocide, crimes against humanity, war crimes, and the crime of aggression), states, regional organisations and the international community have a moral responsibility to intervene in such extreme cases. In Africa's case, intervening for humanitarian purposes is of special significance since the level of human suffering on the continent is distinctly high. In this regard, the study highlights Africa's recent commitment of overturning its traditional posture of non-intervention in the affairs of states, particularly those governments guilty of violating serious international law crimes.

\section{The difficulty in defining and accepting the notion of humanitarian} intervention

Because the term 'intervention' has been used in so many contexts, from interference to meddling to forcible intervention, often there is confusion as to its

V. Gamba and J. Potgieter, 'The challenges to multifunctional peace support operations, ISS Monograph Series, No 8 (January 1997), "Multi-functional peace support operations: evolution and challenges", p 54. 
meaning or definition. ${ }^{4}$ A definition of 'humanitarian intervention' that might find little disagreement is proposed by deLisle, inasmuch as he defines it as

the use or threat of force by a state or states in order to alter institutional structures, or practices inside a target state in such a way as to stop or prevent severe human rights law violations or humanitarian law violations. ${ }^{5}$

Often, confusion exists between what is meant by human rights law and humanitarian law, so it would be useful to clarify the difference between the two before the discussion continues. In brief, international humanitarian law, encoded in the Geneva Convention of 1949 and the two additional protocols of 1977, governs the waging of war and the treatment of combatants and civilians in time of war as stipulated. Human rights law, on the other hand, is primarily concerned with relations between states and their nationals in times of peace. Serious violations of human rights law include the crime of genocide, crimes against humanity, and war crimes. These crimes are defined in relative detail in the recently ratified Rome Statute of the International Criminal Court. ${ }^{6}$ What human rights law and humanitarian law have in common is that they are both concerned with upholding and defending the status and rights of the individual.

Like most other definitions of intervention, a major problem with the concept of humanitarian intervention is that its use runs counter to the traditional norm of not intervening in the internal affairs of other states. Humanitarian grounds for intervening complicate matters even more as they not only entail an exception to the sovereignty and autonomy of the nation state but they clearly evoke the protection of human rights and humanitarian laws. There can be little doubt that the trend after the Second World War has been towards a stronger recognition and need to upgrade the status of human beings in international law. Up until 1945, the practice of international law was almost exclusively concerned with relations between states. Today, however, it is commonly asserted that the role of the state in the international system has shifted somewhat and has been subject to a process of reinterpretation (and hence undermined state-centred thinking) in the humanitarian and human rights fields.

4 A. du Plessis, 'Military intervention: nature and scope', in L. Du Plessis and M. Hough, Managing Africa's conflicts: the challenge of military intervention, HSRC: Pretoria (2000), p 5.

5 J. de Lisle, 'Humanitarian intervention: legality, morality, and the Good Samaritan', Orbis, 45/4 (Fall 2001), p 536.

The Rome Statute (UN) doc. A/CONF.183/9) may be found in the United Nations official website at http://www.un.org/icc, 13 August 1999. 
At a more general level, the various processes of globalisation have also had a positive effect in promoting certain values that have been considered to be incompatible with the more traditional state-centric approach. Amongst other things, these values include limiting the role of the government and promoting good governance, democracy and human rights.

Altogether, these developments have made humanitarian intervention more immediately relevant, and, of course, more controversial. At the heart of the humanitarian intervention debate lies the question of whether force can be used lawfully in situations other than those foreseen by the UN Charter. In order to clarify the legal dimensions of humanitarian intervention the next section will briefly concentrate solely on the international law aspects of what is usually referred to in international law parlance as 'intervention'.

\section{Intervention and international law}

Since a state's right to sovereignty (i.e. its territorial integrity and political independence) is paramount in international law, any type or form of intervention is forbidden. ${ }^{7}$ The theory of sovereignty implies that a state cannot be ruled from an external source, but that the main decisions about its actions must come from within it. $^{8}$ The UN Charter also contains a general prohibition on the use of foreign forcible intervention. Should intervention involve armed forces, Article 2(4) of the UN Charter explicitly prohibits the 'threat or use of force against the territorial integrity, or political independence of a state in any manner inconsistent with the Purposes of the UN ${ }^{, 9}$ In other words, intervention which international law outlaws is intervention by (military) force.

However, despite international legal principles forbidding states to intervene directly or indirectly in the internal and external affairs of other states, there are numerous examples in recent history of states doing just the opposite; the pace of interventions has, if anything, picked up in the last few decades. ${ }^{10}$ Since the 1980s, the United States of America (US) alone has been involved in at least twelve military interventions - most notably in Lebanon (1982), Grenada (1983), Panama (1989), the Persian Gulf War (1990/1), Somalia (1992/3), Haiti (1993), and the former Yugoslavia (1993-1999).

G. Barrie, 'South Africa's forcible intervention in Lesotho: what does international law say?' De Rebus (January 1999), p 46.

M. Malan, 'The Principles of non-interference and the future of multinational intervention in Africa', African Security Review, 6/3 (1997), pp 32-33.

UN, Charter of the United Nations, Article 2(4).

R. Haass, Intervention: the use of American military force in the post-Cold War world, Carnegie Endowment: Washington (1994), p 21. 
The UN Charter allows for only two exceptions to the rule of nonintervention: one is in response to an armed attack (Article 51); the other is when the use of force is authorised by the UN Security Council to maintain or restore international peace and security (Article 42). ${ }^{11}$ Barrie outlines further reasons that have been accepted traditionally by international law as giving states, regional organisations, and/or international organisations justification for intervening in the affairs of another state. They are: a state's right to protect its citizens abroad; to assist peoples in their right to self-determination; as a result of a state formally consenting another party to intervene; and humanitarian intervention. ${ }^{12}$

The last reason, in particular, has been a controversial issue because those who defend humanitarian intervention, commonly regard it as a right 'that comes into being when a state renders itself guilty of cruelties against and persecution of its nationals in such a way as to deny their fundamental rights' ${ }^{13}$ The central argument here is that the interests of humanity in these circumstances outweighs the prohibition on intervention. These circumstances are generally considered as morally unacceptable acts that, in some way or the other, affect all states in the international system. Despite this, unauthorised and/or unilateral intervention poses problems for most states.

Apart from the (well-merited) fear that the US and her allies may abuse the right to interfere in the affairs of other states, the absence of a legal framework for carrying out interventions contributes to the unease states experience when considering such actions. The current system, whereby force is only authorised by the UN Security Council, unfortunately appears to be an insufficient warranty that the Council will intervene when the next human atrocity occurs.

Related to this, historical analysis suggests that economic sanctions and (to a lesser extent) the threat of criminal prosecution are by enlarge weak deterrents and even weaker instruments of compellence. ${ }^{14}$ Specifically, the assumption that economic measures are necessarily the more humane approach to end inhuman treatment by government leaders has been severely undermined by claims that

11 C. Oudraat, 'Humanitarian intervention: the lessons learned', Current History, 99/641 (December 2000), p 421.

12 Barrie, 'South Africa's forcible intervention in Lesotho', op cit., $\mathrm{p} 47$.

13 G. Barrie, 'International law and forcible intervention: a millennium assessment', in L. Du Plessis and M. Hough, Managing Africa's conflicts: the challenge of military

$14 \quad$ intervention, HSRC: Preto 
economic sanctions fall disproportionately on the population rather than the leadership. ${ }^{15}$

Considering the broad overview of the legal dimensions of intervention, the discussion in the subsequent section will review how certain factors in the post-Cold War era may favour intervention as a possible course of action in ending humanitarian crisis in conflict ridden regions such as Africa.

\section{Factors inducing humanitarian intervention in the post-Cold War era}

Vertzberger $^{16}$ suggests that intervention decisions mainly depend on the nature of a specific international system. Thus, different systems have distinct rules regarding the tolerance for the use of forcible intervention as an instrument of foreign policy. Bearing in mind Vertzberger's reasoning, and that intervention is neither a new phenomenon, nor tied to any particular international system, an overview is given of specific attributes of the post-Cold War era and its outcomes with regards to the use of intervention as a viable tool to alleviate human suffering.

\subsection{The 'myth of sovereignty'}

It is often suggested that the post-Cold War political era is characterised by the dissolution of traditional boundaries ${ }^{17}$ and the relative weakening of the nationstate. $^{18}$ As a result of these alleged developments, a number of scholars ${ }^{19}$ have suggested that the concept of sovereignty has become a relative one. As mentioned previously, the legal doctrine of sovereignty stresses a government should be in control of both its own behaviour and affairs. This implies that, in order to enjoy sovereignty, governments must also enjoy legitimacy i.e. the belief that a government has a right to exercise political authority over the rest of its cotizens. ${ }^{20}$ Yet, consider some of the more challenging characteristics of the international system: the increasing marginalisation of the South; the exacerbation of the internal weaknesses of many developing countries; the prevalence of regional conflicts and

15

J. Baylis et al (ed), Strategy in the contemporary world: an introduction to Strategic Studies, Oxford University Press: Oxford (2002), p 57.

16 E.I. Vertzberger, 'International milieu and foreign military intervention: when and how much does the milieu matter?', Journal of Strategic Studies, 17/3 (September 1994), p 142.

17 J. Richardson, 'Strategic thinking in an era of intervention', Comparative Strategy, 18/1 (March 1999), p 32.

18 Malan, op cit., pp 32-33.

19 See for example S. Strange, The retreat of the state - the diffusion of power in the world economy, Cambridge University Press: Cambridge (1996), xvii + 199 pp.

20 A. Thomson, An introduction to African politics, Routledge: London (2000), p 99. 
internal war, enhanced by the resurgence of ethnic nationalism and religious fundamentalism. ${ }^{21}$

Surely those states, when confronted with international indignation over human rights law and humanitarian law violations, have lost their right to invoke the principle of sovereignty? And those governments, which have lost control over their armed forces to massacre civilians, have surely lost their legitimacy, in the eyes of their people, as well as those of the international community? ${ }^{22}$

Cilliers and Sturman conceptualise this problem as the 'myth of sovereignty', a term used to underline the fact that a number of African states do not have the power, authority or competence to govern their own territory. ${ }^{23}$ It is suggested that the absence, or gradual disappearance, of a functioning government can lead to the same kind of human catastrophe as the presence of a repressive state. In considering the emergence of human rights and humanitarian law - both seen as fundamental tools in improving the status of the individual under international law since 1945 - scholars such as Wheeler content that there is an emergent norm in international society that governments that commit the most serious crimes under international law should forfeit the protection afforded them by the rules of sovereignty and non-intervention. ${ }^{24}$

In practice, the UN has frequently been unable to produce consensus among its members to act, and to infringe on the sovereign rights, against governments culpable of committing mass human atrocities. The fact that UN action appears to be mainly driven by the interests of its more powerful members, as the tragic events in Rwanda in 1994 testify, have certainly contributed to the accusation that the organisation appears sometimes unwilling to act.

Despite this, specific events in the 1990s appear to have enlarged consensus about the justification for humanitarian claims, ${ }^{25}$ and may have raised new expectations of a new doctrine of humanitarian intervention. The North Atlantic Treaty Organisations' (NATO) Balkan interventions in the mid-1990s, ${ }^{26}$ for

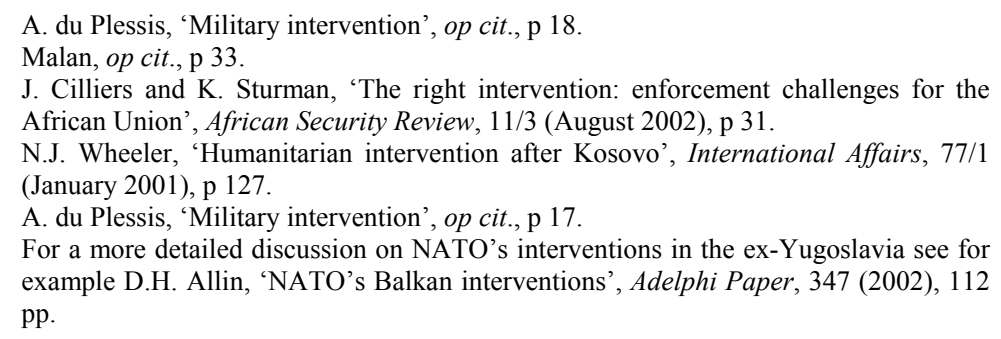


example, demonstrated the readiness of certain countries to undertake humanitarian interventions.

On the whole, therefore, it appears that the incentives for humanitarian intervention, specifically driven by domestic political imperatives, are likely to be more prominent as the pillars of the Westphalian system of state sovereignty appear to be decaying, while the emphasis on defending human rights and humanitarian laws of war seem to be gaining ground. ${ }^{27}$ In order to prevent, manage or resolve conflicts that may involve mass human atrocities, it becomes necessary to understand their origin. Hence, some explanation of conflict, particularly in the case of Africa, will be examined in the following section.

\subsection{The nature of conflict}

Kofi Annan noted in his 1998 report on The causes of conflict and the promotion of durable peace and sustainable development in Africa ${ }^{28}$ that the causes of African conflicts are multifaceted and included historical, external, and internal factors. In this regard, some African commentators and leaders have looked at conflict 'from the prisms of the continent's colonial past' ${ }^{29}$ and the effects of the Cold War in shaping the African state system. Crises of legitimacy, a lack of political accommodation, and the existence of weak states appear to be other major factors contributing to African conflicts.

Colonialism is commonly blamed for creating the conditions for many ethnic grievances of the post-independence era, particularly through arbitrarily drawn colonial boundaries. Indeed, unresolved disputes concerning inherited colonial borders resulted in post-independence conflicts between Burkina Faso and Mali, Nigeria and Cameroon, and Morocco and Algeria. Irredentism claims have been made by Morocco in Western Sahara, Somalia in Ethiopia, and Libya in Chad. ${ }^{30}$ At independence, the new African leadership inherited a country with a political system based on an order that they opposed little or no resources or even the adequate means to acquire them, high illiteracy rates, and poor social and economic infrastructures. Worst of all, conflict in the post-colonial state can be attributed to the fact that many governments have been unable to sustain ethnic unity or provide new incentives for the nations or tribes to live together.

$27 \quad$ Vertzberger, op cit., p 153.

28 K.A. Annan, The causes of conflict and the promotion of durable peace and development in Africa, http://www.un.org.ecosocdev/geninfo/afrec/sgreport/index.html, April 1998.

29 A. Adebajo and C. Landsberg, 'Pax Africana in the Age of Extremes', The South African Journal of International Affairs, 8/2 (2000), p 12.

30 Ibid. 
The Cold War affected the African state-system by prolonging conflict, ${ }^{31}$ and skewed the nature of peace and security as it encouraged the division of the continent into pro-Western and pro-Marxist client-states. ${ }^{32}$ During the Cold War, aid flows were high because the major powers were motivated to ensure the continuing support of their clients. But there was a cost. ${ }^{33}$ Where conflict did erupt, the African continent was inevitably flooded with arms which allowed strong centralised government to enforce their authority through large standing armies. ${ }^{34}$

At the end of the Cold War, there appears to have been little effective demobilisation in Africa. Today, the remnants of large armies still remain in the continent, contributing to new areas of conflict or sustaining factional irregular armed groups which threaten both domestic stability and security. ${ }^{35}$ In this context, the conception of security has largely been promoted in mainly militaristic terms which, in turn, has driven states and governments away from focusing on the needs of peoples. Instead, governments have promoted the concept of security through narrowly defined (military) national security interests, and as a result the security of citizens has often been overlooked and neglected. ${ }^{36}$

As such, a number of Africa's post-independence leaders, notably through their brutal power struggles and politics of social exclusion, have also contributed to conflicts on the continent. ${ }^{37}$ This explanation is often referred to as the "crises of governance' facing Africa. ${ }^{38}$ The African state became a highly contested arena, and spawned an era of personalised rule. The centralisation of state power by autocrats preserved their own rule but eventually led, in cases like Ethiopia, Liberia, Zaïre and Somalia, to injustices that perpetuated the very conflicts they claimed to be attempting to avoid. ${ }^{39}$ These predatory governments, operating through coercion, corruption and personality politics to secure political power and control of resources, ${ }^{40}$ are largely responsible for what is often referred to as the 'collapse' or the 'disintegration' of state institutions. Generally speaking, then, the concept of a

$31 \quad$ Ibid

32 I.A. Gambari, 'Africa and the United Nations in the 21st Century: challenges and prospects', paper presented at the Africa Centre, London, 7 February 2001, http://www.Africacentre.org.uk/UNGambari.htm.

33 Anon, 'The causes of conflict in Africa', Foreign and Commonwealth Department for International Development and the Ministry of Defence Consultation Document, (March 2001), pp 7-8.

Adebajo and Landsberg, op cit., p 13.

Anon, 'The causes of conflict in Africa', op cit., p 8.

Gambari, 'Africa and the United Nations in the 21st Century', op cit.

Adebajo and Landsberg, op cit., p 14.

Gambari, 'Africa and the United Nations in the 21st Century', op cit.

Adebajo and Landsberg, op cit., p 14.

Anon, 'The causes of conflict in Africa', op cit., p 13. 
'nation-state' in the Western sense is often difficult to envisage within the boundaries of these countries.

Lacking political legitimacy and political compromise, often no concept of nationality exists, communal and tribal loyalties still form the central core of the society, and the visible symbols of national identity are both few and unimportant. ${ }^{41}$ Although there are examples in Africa of capable and effective governments, like Botswana and Mauritius, the other end of the spectrum has witnessed more cases where governance has disintegrated into protracted civil wars and lawlessness. These states include Angola (since 1975), Burundi (since 1993), the DRC (since 1997), Guinea-Bissau (1997-99), Côte d'Ivoire (since 2002) Liberia (since 1989), Sierra Leone (1992-99), Somalia (since 1991), and Sudan (since 1983). In most cases, large slices of states bordering these countries have suffered the spillover effects of conflict. ${ }^{42}$

The trend of internal crises, exacerbated by intra-state wars, will most likely continue well into the future because civil and mixed conflicts, involving sub-state groups fighting for political, economic, social and individual reasons, where national governments are unable to govern their territories effectively, is expected to be the norm. As a result, the international community will continue to be characterised by a predominantly peaceful centre (the Developed World) and a peripheral area (the Developing World), distinguished by high levels of persistent civil strife, ethnic nationalism, resource scarcity and a demand for raw material, and religious fundamentalism. The potential for conflict in the periphery is also expected to be much higher, owing to the declining ability and willingness of the UN to secure the international order. ${ }^{43}$

In considering the relationship between humanitarian intervention and the patterns and sources of conflict in Africa, one important factor stands out: the very nature of expected conflict may favour intervention as a preventive response. Indeed, Solomon suggests that conflict on the African continent is often 'resistant' to negotiation. ${ }^{44}$ It is argued that the 'negotiation process functions best under conditions of equality, where all parties have some form of veto over the outcome'. 45

41 A.A. Said, C.O. Lerche Jr, and C.O. Lerche III, Concepts of international politics in global perspective, $4^{\text {th }}$ Ed, Prentice Hall: New Jersey (1995), $\mathrm{p} 35$.

42 A. Gelb, Can Africa claim the $21^{\text {st }}$ Century?, World Bank Publications (April 2000), pp 54-55.

43 A. du Plessis, 'Military intervention', op cit., pp 23-24.

44 H. Solomon, 'South African foreign policy, preventive diplomacy and the false promise of conflict resolution', South African Journal of International Affairs, 9/2

45 (Winter 2002), p 153.

Scientia Militaria, South African Journal of Military Studies, Vol 32, Nr 1, 2004. http://scientiamilitaria.journals.ac.za 
Because these conditions do not always exist in Africa, conflicts on the continent and their root causes create the typical conditions under which the use of intervention can (and should) be considered and justified particularly along humanitarian lines. ${ }^{46}$

Although the desire to postpone armed intervention is understandable, in situations of extreme human suffering, it can also be ill advised. For example, Haass explains that military action by NATO forces against the Serbs around Sarajevo in February 1994 led many observers to argue that force should have been introduced earlier to spare Bosnia's Muslims much of their misery. ${ }^{47}$ In this case, it is suggested that the passage of time increased the amount of territory held by the Serbs, the human suffering, and 'the bitterness that makes any sort of reconciliation highly unlikely'. ${ }^{4}$

\subsection{Emerging ethical considerations}

Ethical considerations have often been regarded as an "enemy" ${ }^{49}$ of the ruling norms and principles of international relations. In fact, with reference to humanitarian intervention, ethical concerns are a primary source of justification for the intervenient use of military force. From a moral standing, Wheeler notes that to qualify as a legitimate humanitarian intervention there has to be a legitimate humanitarian emergency 'where the level of human rights abuses shocks the moral conscience of humanity [and where there is] a strong believe that the intervention will produce a positive humanitarian outcome'. ${ }^{50}$ A second threshold criterion is proposed by Garrett who concludes that 'humanitarian outcomes are more important than motives'. ${ }^{51}$ In other words, unauthorised intervention by a state with no humanitarian motives may be preferable to inaction if this genocide and mass murder.

A good example of international inaction is Rwanda. Although more than a half-a-million people were butchered in genocidal slaughter by rival tribal tribes in the country between 1993-1994, it is frequently alleged that the West did not intervene because there were no significant (Western) national interests at stake. Needles to say, the failure to prevent and end genocides is perhaps the most

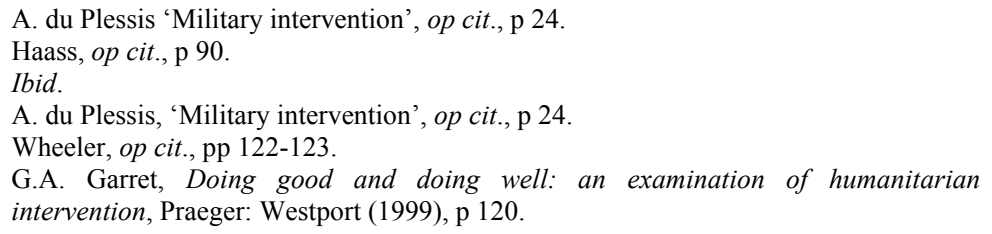


appalling example of Western inaction in the 1990s. ${ }^{52}$ Moreover, it appears that the UN had knowledge that a genocide was being planned and executed, but this information seems to have been (perhaps willingly) lost within its complex bureaucratic structures. ${ }^{53}$ Thus, the response to a particular crisis seems to have depended mainly upon the interest and will of one or more of the great powers and the inability of the UN to act decisively. Arguably, this trend is likely to continue.

At the same time, a failed intervention can do as much damage as failing to intervene at all. ${ }^{54}$ The Somalian disaster showed that an inappropriate response to complex emergency situation can lead a situation from bad to worse. ${ }^{55}$ The ad hoc and sometimes seemingly arbitrary nature of the interventions that have taken place in the past has given many governments cause for concern, and the stakes in the intervention debate are therefore extremely high, especially for Africa. On one hand, many lives can be saved. On the other hand, there is the real danger that poorly planned and executed interventions will do more harm than good, while at the same time weakening the norm of non-intervention and the credibility of the UN. ${ }^{56}$ However, in order to prevent such human catastrophe in the near future, it could be argued that the ethical context should come into play as a necessary condition for the reversal of (negative) perceptions regarding the usefulness of intervention in contemporary world politics. ${ }^{57}$

By taking into account how systemic imperatives, the nature of conflict and moral dilemmas have favoured intervention as a possible, and often preferable, course of action in ending humanitarian-related crises, a fresh dynamism and innovation to the process of preventing and managing conflicts in Africa is required. ${ }^{58}$ Perhaps the most workable system in dealing with conflicts is to place more emphasis and reliance on regional organisations.

$52 \quad$ Wheeler, op cit., p 126.

53 V. Seymour, Burundi and the future of humanitarian intervention, ISS Occasional Paper No 9 (September 1996), p 3.

Cilliers and Sturman, op cit., p 29.

Ibid.

S.J.T.M. Samkange, 'African perspectives on intervention and state sovereignty', African Security Review, 11/1 (2002), p 74.

57 Cilliers and Sturman, op cit., p 25.

58 K.N. Mulikita, 'The United Nations Security Council and the Organisation of African Unity: conflict or collaboration?', African Security Review, 11/1 (2002), p 31. 


\section{The necessity to become more self-reliant: enter African regionalism}

Rather than the UN's envisioned involvement in peace missions, ${ }^{59}$ it is widely acknowledged, and also well recognised by most leaders of less powerful states, that the more powerful members of the UN are eager to delegate responsibility for peace missions on to (sub) regional bodies such as, in Africa's case, the African Union (AU), the South African Development Community (SADC), and ECOWAS. ${ }^{60}$ Factors that have influenced the decline of international commitment in conflict management, and resolution in Africa, and hence the growing reliance on 'regionalisation', appear to be twofold.

The first factor relates to the apparent strategic marginalisation of the continent. The strategic importance the Cold War accorded Africa has, for the most part, declined. This loss of strategic value has dramatically affected the stability of sub-Saharan Africa. Whereas both Moscow and Washington had once worked hard to keep particular governments in firm control, the incentives to do so in the postCold War years have evaporated. ${ }^{61}$ Secondly, negative experiences with peace missions in chaotic sub-Saharan conditions have generally convinced Western powers that such operations may not be in their national interests. Since the ill-fated intervention in the inter-clan conflicts in Somalia in 1992 and 1993, even the US (with its long history of intervening in the affairs of other states) has become cautious about becoming involved in African conflicts. ${ }^{62}$

These two factors have largely influenced Western approaches in solving African conflicts. In essence, this approach appears to be centred on resolving conflicts through political dialogue and negotiations, rather than through any kind of military action.

What has made matters even worse for Africa, is that the UN has generally proven unable to meet the high expectations in the field of peace missions in the aftermath of the Cold War. According to UN Secretary-General Kofi Annan

The [UN] does not have, at this point in its history, the institutional capacity to conduct military enforcement measures under Chapter

59 The UN uses the expression 'peace mission' as a generic term to include all political, diplomatic and military activities related to multinational events to prevent manage and settle disputes in terms of the UN Charter, including humanitarian intervention operations.

Cilliers and Sturman, op cit., p 31.

Falk, op cit., p 374.

L. du Plessis, 'African conflict at the turn of the century: manifestations, propensity and management', in L. Du Plessis and M. Hough, Managing Africa's conflicts: the challenge of military intervention, HSRC: Pretoria (2000), p 150. 
VII of the Charter [and the UN] still lacks the capacity to implement rapidly and effectively decisions of the Security Council calling for the dispatch of peacekeeping operations in crisis situations. [Moreover,] peacemaking and human rights operations [also] lack a secure financial footing, which has a serious impact on the viability of such operations. ${ }^{63}$

This line of thought is also captured by Neethling who argues that the UN has proven unable to deploy robust forces that are capable of conducting peace enforcement operations in brutal conflicts. ${ }^{64}$ Besides the UN's experiences in Somalia and Rwanda, its endeavours in Liberia, the DRC and Sierra Leone have further proven that the UN does not appear in a position to respond meaningfully to humanitarian emergencies in Africa. More seriously, Mulikita argues that there has been a perception often aired by African leaders that the UN upholds a double standard when it deals with peace and security challenges in Africa. ${ }^{65}$ Likewise, in her keynote address to an international symposium on conflict prevention, organised by the Government of Japan and held in Tokyo in March 2000, South Africa's Foreign Affairs Minister, Dr Dlamini-Zuma cautioned:

We have observed over the years that sometimes when the $\mathrm{UN}$ is called upon to act in Africa, it approaches that responsibility with the speed of an elephant whereas when it is asked to act in other situations it approaches at the speed of a cheetah. ${ }^{66}$

Therefore, with reference to the proposed indifference of the UN, and in a world within which African security is of marginal global concern, as well as at a time when the UN and many Western powers have became increasingly unwilling and/or unable to be involved in regional conflicts, many African nations have realised the necessity to become more self-reliant in responding to armed conflict and humanitarian emergencies. This, in turn, has impacted on the manner in which Western and African societies (differently) approach the management and resolution of conflicts on the African continent.

63

K.A. Annan, Renewing the United Nations: a Programme for Reform (A/51/950), http://www.un.org/reform/refdoc.htm, 16 July 1997.

64 T. Neethling, 'The emerging South African profile in Africa: reflections on the significance of South Africa's entrance into peacekeeping', African Journal on Conflict Resolution, 2/2 (2002), p 111.

$65 \quad$ Mulikita, op cit., p 31.

66 N. Dlamini-Zuma (Dr) Speech by Her Excellency the Minister of Foreign Affairs of the Republic of South African at the international symposium on the Roles of subregional organisations in conflict prevention and peace initiatives in sun-Saharan Africa, 28 March 2000, Tokyo, Japan. 
In this regard, ECOWAS's experiences West Africa have been hailed as a landmark to the new shape of international peace missions in the post-Cold War period. ${ }^{67}$ True, ECOWAS's real motives for intervening are often questioned, but the organisations endeavours are nonetheless regarded as possibly the first sign of Africa changing its traditional stance towards intervention, from non-intervention in the affairs of other states towards interference in the face of human tragedy.

\subsection{The ECOMOG experience: a revolution in inter-African affairs}

The first signs of Africa overturning its traditional reluctance to approve of intervention in the internal affairs of its member states was demonstrated when the Monitoring Group of ECOWAS (ECOMOG) intervened in Liberia (1991) and in Sierra Leone (1993). ${ }^{68}$ Both countries were embroiled in bloody civil wars characterised by widespread atrocities, human rights violations and sheer human misery on a scale never witnessed before in Africa, and there also appears to have been a total disregard for international conventions and civilised conduct of war. A variety of contending explanations have been put forward by scholars ${ }^{69}$ when examining ECOMOG's reasons for intervening - among them for humanitarian reasons - although the validity of this particular motive is questionable.

Nonetheless, ECOMOG's endeavours in West Africa can be viewed as a major evolution in inter-African affairs for a number of reasons. Firstly, West Africa presented the first example of a sub-regional organisation that intervened military in the domestic affairs of member states at different times in the 1990s.Secondly, the decision to intervene undermined the basic tenets (i.e. the respect of sovereignty and the principle of non-interference) that have guiding relations among many Africa's political leaders since the creation of the OAU. ${ }^{70}$ Thirdly, and perhaps most importantly, the ECOMOG operations set a very important precedent in that they demonstrated that intervention forces force could be mounted without the prior approval of the UN. The two operations were in fact not directly sanctioned by the $\mathrm{UN}$, although they did receive retroactive approval. ${ }^{71}$

This last point comes as no real surprise since ECOWAS's Protocol Relating to the Mechanism for Conflict Prevention, Management, Resolution, Peacekeeping

67 E. Hutchful, 'The ECOMOG experience with peacekeeping in West Africa', ISS Monograph Series, No 36, (April 1999), "Whither peacekeeping in Africa?", p. 1.

68 K. Aning, 'Towards the new millennium: ECOWAS's evolving conflict management system', African Security Review, 9/5-6 (2000), pp 51-63.

69 See for example A. Sesay, 'West African military interventions in the 1990s: the case of Liberia and Sierra Leone', in L. Du Plessis and M. Hough, Managing Africa's conflicts: the challenge of military intervention, HSRC: Pretoria (2000), 193-253 pp.

70 Aning, op cit., p. 51.

71 Sesay, op cit., p. 235 
and Security ${ }^{72}$ (the 'Protocol') does not explicitly call for prior UN approval for humanitarian actions. In cases of internal conflict that may trigger a humanitarian disaster, and where serious violations of human rights may occur, Article 27 of the Protocol only states that ECOWAS 'shall submit a report on the situation to the Organisation of African Unity and the United Nations', ${ }^{73}$ while Article 52 merely affirms that ECOWAS 'shall inform the United Nations of any military intervention undertaken in pursuit of the objectives of ECOWAS' ${ }^{74}$

It is perhaps because of ECOWAS's singular stance and relative success in ending humanitarian disaster in both Liberia and Sierra Leone (as opposed to the UN which, at that stage, seemed generally unwilling to act even in the face of grave human atrocities), that inspired African Heads of State and Government to embrace a distinctly African approach to conflict prevention, management, and resolution by adopting the Constitutive Act of the AU in Lomé, Togo, on 11 July 2000. ${ }^{75}$

\subsection{The African Union's Constitutive Act: asserting Africa's own priorities}

Africa's traditional posture of non-intervention in the internal affairs of other states was largely overturned with the establishment of the AU. Indeed, the Constitutive Act of the AU allows for intervention without the consent of the target state in a way that the former Organisation of the Africa Union (OAU) never did. Article 3 of the OAU Charter ${ }^{76}$ states, amongst other principles, the strict adherence to

the sovereignty equality of all member states; non-interference in the internal affairs of States; respect for the sovereignty and territorial integrity of each state; and for its inalienable right to independent existence. ${ }^{77}$

In stark contrast, Article 4(h) of the AU provides for the right to of the African Union intervene in a Member State [in] respect of

ECOWAS's Protocol Relating to the Mechanism for Conflict Prevention, Management, Resolution, Peacekeeping and Security may be found at the Institute for Security Studies' (ISS) website at http://www.iss.co.za/AF/RegOrg/unity_to union/pdfs/ecowas/ConflictMechanismProtocol.pdf.

ECOWAS, Protocol, Article 27.

ECOWAS, Protocol, Article 52.

The Constitutive Act of the AU may be found in the official website of the South African Chairmanship of the African Union at http://www.au2002.gov.za/docs/key_oa $\mathrm{u} / \mathrm{au}$ act.htm.

76 The OAU Charter may found in the official website of the South African Chairmanship of the African Union at http://www.au2002.gov.za/docs/key_oau/oau_c harter.htm, adopted in Addis Ababa, Ethiopia, 25 May 1963.

77 OAU, OAU Charter, Article 3 (1-3). 
grave circumstances, namely war crimes, genocide and crimes against humanity[.] $]^{78}$

The AU's act also provides much leeway in the criteria for intervention in as much as Articles 4(m), 4(o), and 4 (p) respectively provide for the respect for democratic principles, human rights, the rule of law and good governance; respect for the sanctity of human life, condemnation and rejection, acts of terrorism and subversive activities; and condemnation and rejection of unconstitutional changes of government. $^{79}$

Although it may be true that African leaders have generally been slow to ratify many treaties and protocols, and have often lacked the necessary political will to undertake what they have committed themselves to do, this position taken by the member states of $\mathrm{AU}$ is nonetheless important for a number of reasons.

First of all, the AU Act is the first international treaty to recognise the right to intervene for humanitarian purposes. ${ }^{80}$ Secondly, it reflects a growing recognition that the principle of sovereignty cannot, and should not, be used as a barrier by which oppressive leaders may continue to abuse their people. ${ }^{81}$ Thirdly, if leaders are held responsible of abusing their people, intervention will be considered as a means to end violence and restore peace. Lastly, and perhaps most significantly, it appears as if Africa (at least on paper) is defining and asserting its own priorities. In this regard, the AU Act seems unclear with regards to prior UN authorisation for intervention. Certainly, African leaders should ideally seek initial UN approval for intervening. But the AU, compared to its predecessor, has undoubtedly struck a somewhat unique relationship with the UN, especially since it appears that the organisation, at this stage, has sufficient leeway to sanction intervention missions on the African continent.

\section{Towards a new co-operative framework between the AU and the UN}

Article 24(1) of the UN Charter specifically confers on the UN Security Council "primary responsibility for the maintenance of international peace and security'. ${ }^{82}$ Unfortunately, international realities dictate that the UN cannot address

\footnotetext{
78 AU, Constitutive Act of the $A U$, Article 4(h).

79 AU, Constitutive Act of the AU, Article 4(m), Article 4(o), and Article 4(p).

80 E. Baimu and K. Sturman, 'Amendment to the African Union's right to intervene: a shift from human security to regime security?', African Security Review, 12/2 (2003), p. 40.

81 L. du Plessis, 'Conclusion: the challenge of military intervention', in L. Du Plessis and M. Hough, Managing Africa's conflicts: the challenge of military intervention, HSRC: Pretoria (2000), p 337.

82 UN, Charter of the United Nations, Article 24(1).
} 
every potential and actual conflict troubling the world, ${ }^{83}$ while, at the same time, regional organisations such as the AU often operate with starved resources and have limited capacity to provide security. ${ }^{84}$ Two solutions that might help overcoming these international realities and regional shortcomings are subsequently proposed.

\subsection{The 'layered response' system}

Both Vraalsen, Cilliers and Sturman propose that a 'layered response' system is an effective mechanism to overcome the difficulties faced by international and regional organisations when dealing with conflicts. ${ }^{85}$ In essence, this system favours local and regional responses to a problem before the UN Security Council becomes involved. Although this would practically mean a dilution of the central role many had hoped that the UN would play in peace missions world-wide, the layered response system is envisioned in optimising the use of available resources. In other words, should local resources prove insufficient, then the next layer is responsible for providing the necessary means and material to effectively respond to any serious crises.

In Africa's case, the AU is the ideal regional body to respond to conflicts anywhere on the African continent. In the same way, sub-regional organisations like SADC and ECOWAS are ideal to respond to more locally-based conflicts. In sum, these organisations should be viewed as important links in the chain of a layered response, and, depending on their particular mandates, have specific but related responsibilities.

Unfortunately, the track record of the AU's predecessor, the OAU, has not been impressive in either preventing, managing, or resolving African conflicts. Caught in its perennial dilemma of wanting to promote peace in cases of civil war, the OAU has almost without exception been a defender of the status quo, mainly in terms of national boundaries, of how various countries are structured, and of political leadership. These positions, although understandable, have severely limited the opportunities to protect people living in states guilty of violating the rights of millions of individuals. ${ }^{86}$ Sure, the AU's position on intervention challenges Africa's traditional (negative) posture towards intervention, but is also true that the realities of African politics dictate a more meaningful search for measures to enhance the competence of the AU in either initiating, participating, or be willing to

\footnotetext{
83 T. Vraalsen, 'Thinking about peace and peace-keeping and peace-making in Africa', in G.M. Sørbø and P. Vale, Out of conflict: from war to peace in Africa, Mottle: Grafiska, Sweden (1999), p 31.

$84 \quad$ Cilliers and Sturman, op cit., p 30.

$85 \quad$ Ibid.

$86 \quad$ Vraalsen, op cit., p 32.
} 
conduct humanitarian intervention operations - or any other type of peace mission for that matter.

Present international norms on the allowance of intervention further complicate this possibility. In terms of the UN Charter, any (sub) regional organisation that intends to undertake any intervention actions, must seek the prior authorisation of the UN Security Council. The principles of most regional organisations reflect this approach. But what happens if the UN Security Council is unwilling or unable to authorise appropriate action in a timely manner as happened in the case of Rwanda?

As already mentioned, the act establishing the AU is not clear in this regard, leaving sufficient leeway for the AU to sanction intervention without prior UN Security Council approval. ${ }^{87}$ At the same time, the UN has been almost blind in assuming the supremacy of the principle of non-interference and has, therefore, proved willing to authorise intervention in humanitarian crises only where the consent of the major parties to such conflicts has been obtained. ${ }^{88}$ Abidance to this principle has led to inaction. In such circumstances, contemporary crises in Africa involving human atrocities have challenged the quality of 'consent' as a prerequisite for meaningful intervention. ${ }^{89}$ Perhaps it is time that the strict abidance to this rule is re-considered.

\subsection{Ex-post facto approval}

Keeping in mind that the UN should unquestionably continue to play a central role with regard to peace initiatives in Africa, ${ }^{90}$ it has been argued the AU is morally and legally obliged to do everything it can do to muster forces from its own resources to prevent the recurrence of international inaction - even if this may entail turning a blind eye in the face of UN authority. ${ }^{91}$ Although one would assume that the AU or other regional organisations would not easily embark upon intervention without a mandate from the UN Security Council, it may be necessary to adopt a more versatile and flexible approach once certain conditions with regard to human suffering are reached.

A viable solution to the problem of UN inaction was proposed in October 2001 by the Washington DC-based Fund for Peace through its Programme on

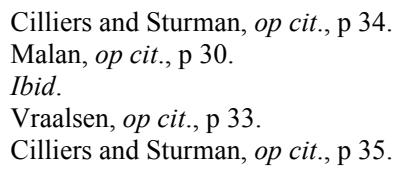


Regional Responses to Internal War. ${ }^{92}$ One of its reports, namely African Perspectives on Military Intervention, suggests that although the UN Security Council is the preferred authorising body for intervention, these missions may be authorised by the $\mathrm{AU}$ or other sub-regional organisation in emergencies in which urgent action is needed, but the UN Security Council must be informed and ex post facto approval must be sought. Sub-regional organisations must likewise inform and seek approval from the $\mathrm{AU} .^{93}$

Against this background, it would appear that (sub) regional role-players in Africa may be compelled to play a more pro-active role in upholding security and defending peace on the continent. This is, of course, of special significance for South Africa, generally perceived as a regional power in Southern Africa and on the continent. The last section of the paper, therefore, will examine whether South Africa has the capacity to positively contribute in enforcing peace missions on the African continent - if necessary, with a view to resolving current and future conflicts through decisive interventions.

\section{South Africa's role in promoting Africa's intervention posture}

South Africa's role in the promotion of security and the sustainability of peace on the continent is generally regarded as being invaluable with regards to the well being and future of Southern Africa, and Africa in general. Pretoria views the plethora of wars on the African continent as 'anathema' to the notion of an African Renaissance. ${ }^{94}$ Ending these conflicts on the continent, therefore, is considered as one of the more important goals of South Africa's foreign policy. Official government documents such as the 1996 White Paper on Defence ${ }^{95}$ and the 1998 Defence Review, ${ }^{96}$ clearly link peace and stability on the continent to the country's national interest.

With regard to intervention, and peace operations in general, Chapter 4 of the White Paper on Defence and Chapter 5 of the Defence Review strictly articulate that such missions ought to take place under the auspices of the (former) OAU or SADC, and that they require prior endorsement by the UN Security Council. Likewise, Article 11 of SADC's political and security 'leg', the Organ on Politics, Defence and

92 M. Locke, 'African perspectives on intervention and internal war', African Security Review, 11/1 (2002), p 87.

93 Fund for Peace, 'African perspectives on military intervention', Building Peace in the $21^{\text {st }}$ Century, Conference Summary, Number 1, December 2001.

94 Solomon, op cit., p 148

95 Republic of South Africa, Defence in a Democracy: South African White Paper on Defence (1996).

96 Republic of South Africa, Defence in a Democracy: South African Defence Review (1998). 
Security, clearly asserts that SADC 'shall resort to [peace] enforcement only with the authorisation of the UN Security Council'. ${ }^{97}$ In all fairness, these conditions do reaffirm their commitment to the principles in the UN Charter, but they certainly do not reflect the current and more flexible approach offered by the AU's Constitutive Act. Now that the AU has been adopted, the question that should be asked is whether the South African government, as well as other SADC member states, are willing to re-consider their posture on intervention.

Considering South Africa's growing global profile, many regional and international actors expect the country to play a prominent role in overturning the current (unstable) state of affairs in and beyond SADC territory. Indeed, there are few countries like South Africa that have the resources and the operational capabilities to maintain enforcement missions for any length of time on the African continent. ${ }^{98}$ Thus, if one considers that humanitarian intervention might emerge as one amongst other issues that could positively contribute to the management, and perhaps even the prevention, of conflict - as this study has attempted to demonstrate - it is proposed that South Africa has important responsibilities to promote a more positive attitude towards humanitarian intervention.

As regional 'superpower', it could be argued that South Africa should take a tougher stand than it presently is in averting inaction in the face of large-scale human suffering. Preventive diplomacy, ${ }^{99}$ which appears to lie at the very heart of South Africa's regional policy, has by enlarge failed to achieve its desired objective of supporting peace and democracy and ending human suffering, particularly in the cases of Angola, the DRC, and Zimbabwe. Internationally, South Africa has the responsibility of promoting the AU's current position regarding intervention based on humanitarian grounds. Of course, this would entail a re-think of Pretoria's own position towards the allowance of humanitarian intervention operations in Southern Africa. In the long term, South Africa should take the lead in pressurising international leaders to adopt a new legal framework regarding intervention similar to the one proposed by the Programme on Regional Responses to Internal War i.e. that intervention may be authorised by (sub) regional organisations in emergencies in which urgent action is needed, in cases, of course, when the UN and powerful states appear to be unwilling or incapable of acting.

97 SADC, Article 11. SADC's Protocol on the Organ on Politics, Defence and Security may be found at the Institute for Security Studies' (ISS) official website at http://www.iss.co.za/AF/RegOrg/unity_to_union/pdfs/unity_to_union/pdfs/sadc/Proto col_on_Defence_Organ.pdf.

98 Solomon, op cit., p 155 .

$99 \quad$ Defined in the South African Defence Review as involving 'diplomatic action taken in advance of a predicted crisis to prevent or limit violence'. 
In view of the above, and to overcome international realties and regional shortcomings, South Africa may emerge as a vital link in the chain of a 'layered response' system between the UN, the AU, and SADC. However, because no African state has a permanent seat on the UN Security Council, interventions by African regional and sub-regional organisations would almost always be subjected to international scrutiny, and the great powers will always have a key role in deciding on interventions. South Africa has, at least by implication, stated its aspiration to become a permanent member of the UN Security Council. ${ }^{100}$ If this aspiration ever materialised, the more powerful states would possibly have less of a chance blocking smaller powers from intervening or nullifying the existence of a humanitarian crisis. Unfortunately, because the opposite is true, it is not hard to appreciate the AU's (perhaps audacious) provisions regarding the criteria and authorisation of interventions. Given the reluctance of many Western powers to engage in peace missions, gaining an African permanent seat on the UN Security Council, therefore, may prove highly valuable.

\section{Conclusion}

In the course of reviewing all the factors discussed in the paper, several important issues have arisen from the discussion. Firstly, individuals have a right to receive humanitarian assistance. Secondly, because the Westphalian system of state sovereignty appears to be disintegrating particularly in Africa's case, intervention missions may not necessarily take place within the context of a system of sovereign states controlled by legitimate and internationally accepted leaders. Thirdly, no state should be allowed to invoke the principle of sovereignty when accused of serious human rights law and humanitarian law violations. Fourthly, because a state's very existence rests on its authority, the presiding authorities cannot be considered legitimate once control is lost over their armed forces. Fifthly, the very nature of expected conflict favours humanitarian intervention as a preventative or coercive response.

All these conditions have convinced a number of academics and international leaders alike that the internal affairs of states have now become a more important component of the present international system. In considering the paper's arguments, it is proposed that bypassing the sovereign rights of a state, if sovereignty is used as protection behind which predatory governments can hide abuse of their peoples, is morally justifiable. Surely, avoiding intervention on this premises is un-justifiable. Certainly, a system whereby the dignity and

100 Anon, 'Mbeki: UN must tackle African crises', $B B C$ News, http://news.bbc.co.uk/1/hi/world/africa/917038.stm, 9 September 2000. 
independence of states is practised, without the misuse of sovereign rights, cannot accept intervention as a means to solve threats to human security, if any. Africa has not (yet) reached this stage of political development, and hence it could be argued that humanitarian intervention in Africa might be needed where a weak state is unable to protect its citizens, as well as when a repressive state is unwilling to do so or it is itself the cause of abuse.

In this regard, the intention recently expressed by the $\mathrm{AU}$ in its Constitutive Act - in terms of not tolerating abusive governments that hide behind the 'barriers' of sovereignty - can be recognised as a huge step forward and a positive opportunity for a reversal of negative perceptions regarding the usefulness of intervention in contemporary world politics. Significantly, the AU's Act is the first international treaty to have recognised the right to intervene for humanitarian purposes. For all intents and purposes, it appears that Africa may well be on the frontline of the intervention challenge, and that the continent is now at the vanguard of international thinking on these issues.

It cannot be overly stressed, however, that any significant movement for Africa in search for regional peace depends, above all, upon the political will of African states. In this respect, recent decisions to agree upon certain rules and procedures that do not tolerate human suffering occurring within the confines of a state give grounds for cautious optimism. True, humanitarian intervention should in most cases be regarded as an action of last resort; but if conducted in a legitimate way it could positively contribute to the management and resolution of violence on the African continent. 